\title{
Benefits of Embungs in the Rawa Pening Catchment Area for Reducing Tuntang River Flood Discharge
}

\author{
Suseno Darsonol, *, Suripin, ${ }^{1}$, Hary Budieny ${ }^{1}$, Risdiana Cholifatul Afifah ${ }^{2}$, Ratih Pujiastuti ${ }^{2}$, Fhanda Soripada ${ }^{3}$, Marshall \\ Indradifa TP Hutagalung ${ }^{3}$, Laksono Adi Pamungkas ${ }^{3}$, Ganang Wahyu Saputra ${ }^{3}$
}

${ }^{1}$ Civil Engineering Department Diponegoro University, Semarang, Indonesia, ${ }^{2}$ Center for Disaster Studies, Diponegoro University, Semarang, Indonesia, ${ }^{3}$ Student of Civil Engineering Department, Diponegoro University, Semarang, Indonesia

\begin{abstract}
Rawa Pening is a natural lake as a source of water for Tuntang River which is used for hydropower, raw water source, main irrigation water source in Glapan weir located in Grobogan District, Central Java provinces. Rawa Pening will be developed as location of national and international ecotourism. An Optimal Water Resources Management is required with several studies. This study is the beginning of a series of studies planned to determine the potential of embungs and its utilization as flood control, sediment control of Rawa Pening and for reducing weeds growth.
\end{abstract}

Keywords: Embung, Flood Control, Rawa Pening

\section{INTRODUCTION}

Tuntang River is a river that originated from Rawa Pening and river flow flows into the Java sea on the north coast of Java Island. The source of the water comes from the natural lake Rawa Pening. Flood in Kab. Grobogan, Central Java Province is a routine thing caused by Tuntang River water flood. This is the main focus because it is an essential foundation for human life, economic growth and progress in the development of Grobogan District, province of Central Java.

Based on the water balance analysis in the "Pola PSDA WS Jratunseluna" study, Rawa Pening water wasted to the sea during the rainy season is still about $80 \%$ of rain water volume per year, so that can be utilized only $20 \%$. Therefore, it is necessary to develop optimal water resources management planning. Ministry of Tourism seeks to make Rawa Pening tourist attraction in District, province of Central Java as a world ecotourism destination that will be integrated with Borobudur Temple tour.

Rawa Pening water is only flows to Tuntang River through one outlet without a control structure. Another problem that occurs in Rawa Pening lake is blooming of weeds of water hyacinth "Eceng Gondok" due to the distribution of sediments with nitrogen and phosphorus content. Even in 2011 weeds of water hyacinth cover the surface area of the lake approximately $1080 \mathrm{Ha}$ or about $70 \%$ of the lake area. This of course inhibits the potential of the lake to become a national and international class tourist because of the difficulty of the application of the lake as a means of water sports and the utilization of other tourist objects.
The purpose of this study is to start for developing an optimal planning of Rawa Pening is to determine the potential location of the small dams (embung-embung) which is useful to reduce the peak hydrograph of Tuntang River floods and increase low flows of Rawa Pening. The following are the objectives of this study;

1. Determine the location of its embungs and subcatchments.

2. Analyze the flood hydrograph before and after built embungs.

3. Arrange the ranking of embung-embung development with the main criterion of the ability to reduce the flood.

4. Analyzing flood mitigation caused by embungs in the Rawa Diving Watershed.

Hyetographs (rainfall-intensity curves) are a description of rain distribution over time and are important in hirological and hydraulic planning [1].

The intensity of the rain is high enough that the rain is influential, then we only focus on rain with high intensity [1]:

1. Separate each rain series (6-hours-criterion)

2. Use a rain series of a total depth of $15 \mathrm{~mm}$

3. Use only events with minimum intensity of $10 \mathrm{~mm} / \mathrm{hr}$ The digital elevation model (DEM) has used to produce the locations of embungs (small dams) and watersheds. Traditional methods use high-resolution topographic maps or field surveys [2]. The synthetic unit hydrograph method is a popular method used and plays an important role in the analysis of flood discharge [3]. The hydrological analysis was performed using HECHMS to simulate the runoff-runoff from precipitation

Corresponding author: sdarsono@hotmail.com 
[4]. The distribution of rain intensity in a particular series of rain called a hyetograph needs to be modeled for a particular area. This study examines the methods of flood control for complex multi-reservoir systems and reviews the sequence of development [5].

Flood routing is an important technic and is needed in water resources management. Although flooding with hydraulic models is often used in flood search analysis, but flooding with hydrological models is simpler and more effective and suitable, as it is often used. The flooding model Muskingum is commonly used as a hydrological model device in this kind of study, where its accuracy depends on the coefficients of $\mathrm{K}$ and $\mathrm{X}$ on the Muskingum model [6]

Streams coming out of the embungs through expenditure or overflow buildings are analyzed using conservation solutions with mass equations that are part of the HECHMS software. The mass equation takes into account the container at a given time, minus inflow at time $t$, plus outflow at the location of the expenditure structure [7].

The initial stage of potential plumbing in the Rawa Pening area needs to be assessed for the type and type of dam [8].

\section{METHODOLOGY}

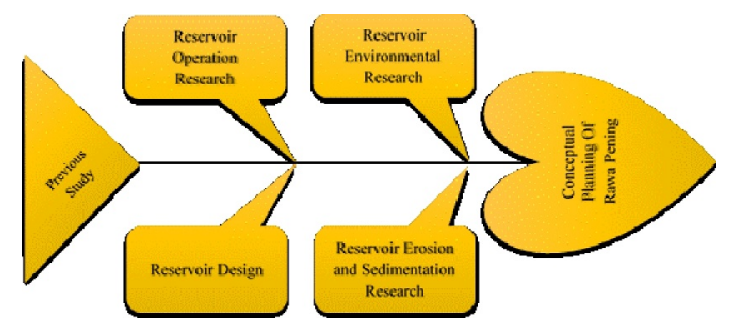

Figure 1. Road Map of Conceptual Planning

Figure 1. is a diagram of the "Road map" of the management plan to achieve the development of tourism in Rawa Pening Lake which is world class but still based on ecotourism which is the government's goal. This study is a study of the potential of embungs that can be built in the watershed catchment to be able to reduce the peak flood and increase the mainstay discharge.

In order to achieve an optimal international ecotourism plan, four research stages or studies should be undertaken as follows;

1. Planning potential embungs that are beneficial for the reduction of flooding out to Tuntang River. In addition, the most optimal sequence of development is done.

2. Conduct an optimization study of dam operations so that the water requirement for hydropower, raw water and irrigation water can be fulfilled at any time according to the needs per year.

3. Conducting soil erosion studies so that it can be planned optimal land use and sediment reduction efforts that occur in Rawa Pening.

The results of the four studies mentioned above are used to develop an optimum Swamp Management plan.

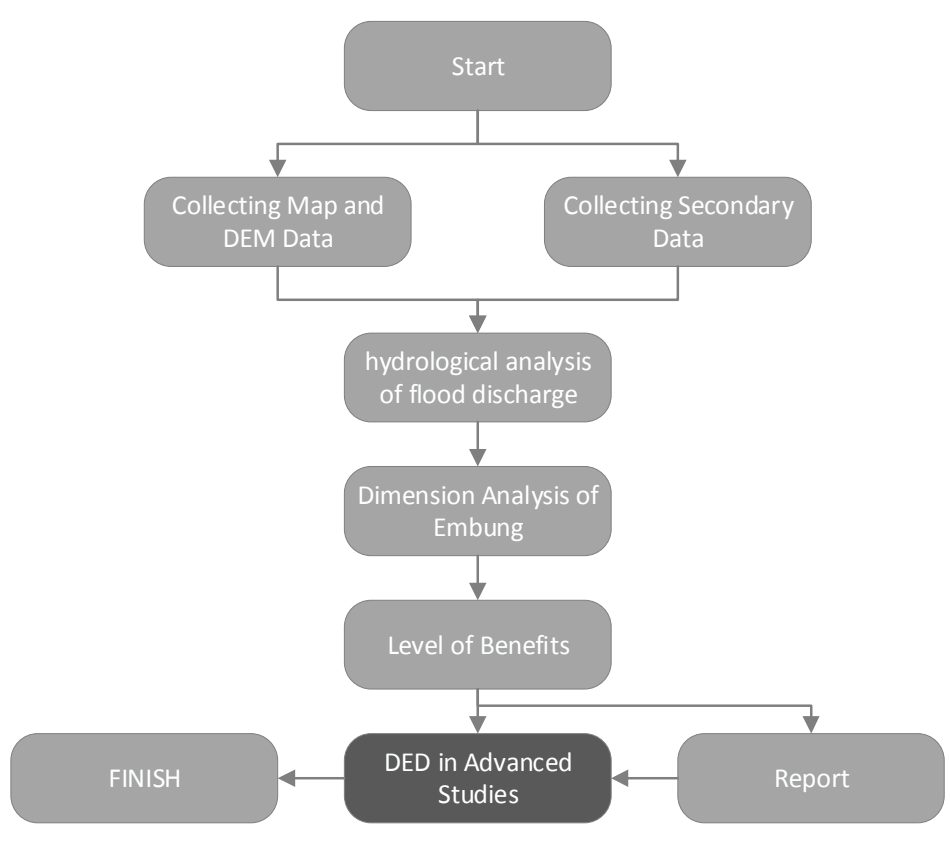

Figure 2. Flow Chart of Research Implementation

Figure 2 below is a detailed description of each activity from the research stage at the initial stage of the optimal Swamp Management plan arrangement:

1. The maps and DEM collected are the following data:

- Topographic maps

- Land use map

- Soil map

2. Secondary data collection in the form of daily rainfall data and previous study results.

3. Hydrology analysis of flood discharge with the help of HEC-HMS software that produces flood hydrograph before and after embung is built.

4. Analysis of the embung dimension of elevation and width of the spillway in the analysis using hydrological model that has been built, thus the embung dimension can be determined.

5. Analysis of the level of benefits is divided into the analysis of the perforated each embung based on multi-criteria model analysis is the model "Weighted average".

6. Reporting in the form of research reports and publications journal. Results of research and discussion.

\section{RESULTS AND DISCUSSION}

From the result of location identification using earth map map and DEM, there are 40 potential locations of embung spread over 16 tributaries. The location and capacity of each embung plan is shown in Figure 3. 


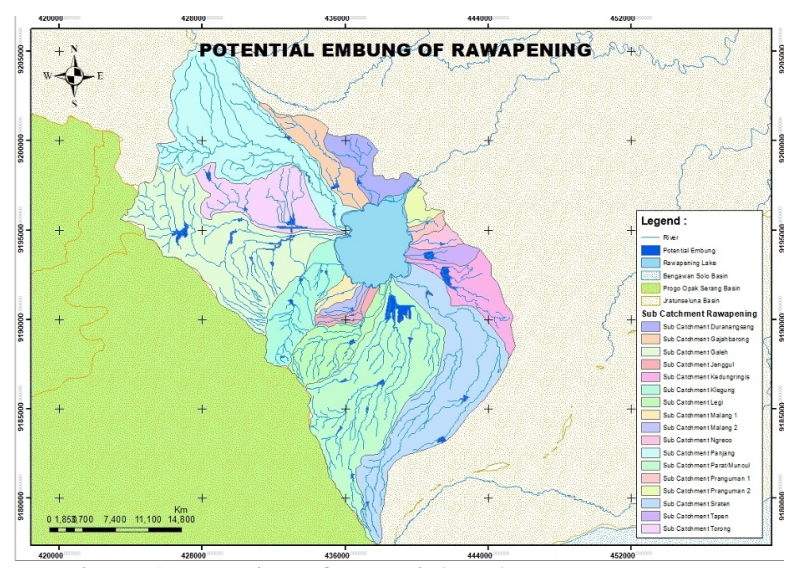

Figure 2. Location of Potential Embungs

To know the discharge reduction of each potential embung modeled flood discharge using HEC-HMS model. The results are displayed on Tabel 1.

Tabel 1. Discharge Redustion of Each Potential Embung

\begin{tabular}{|c|c|c|c|c|}
\hline No & Embung & $\begin{array}{l}\text { Inflow } \\
\left(\mathrm{m}^{3} / \mathbf{s}\right)\end{array}$ & $\begin{array}{c}\text { Outflow } \\
\left(\mathbf{m}^{3} / \mathbf{s}\right)\end{array}$ & $\begin{array}{c}\text { Discharge } \\
\text { Reduction } \\
\left(\mathbf{m}^{3} / \mathbf{s}\right)\end{array}$ \\
\hline 1 & $\begin{array}{l}\text { Embung } \\
\text { Kranggan }\end{array}$ & 120 & 119.3 & 0.7 \\
\hline 2 & $\begin{array}{l}\text { Embung } \\
\text { Lodoyong }\end{array}$ & 147.4 & 146.8 & 0.6 \\
\hline 3 & Embung Kupang & 28.2 & 27.4 & 0.8 \\
\hline 4 & $\begin{array}{l}\text { Embung } \\
\text { Tambakboyo }\end{array}$ & 16.6 & 16.2 & 0.4 \\
\hline 5 & Embung Delik & 2.7 & 2.6 & 0.1 \\
\hline 6 & Embung Lopait & 4.1 & 3.3 & 0.8 \\
\hline 7 & Embung Kesongo & 12 & 10 & 2 \\
\hline 8 & Embung Pramuka & 41.8 & 41.2 & 0.6 \\
\hline 9 & Embung Batur & 6.2 & 6 & 0.2 \\
\hline 10 & Embung Taju & 7.7 & 4.3 & 3.4 \\
\hline 11 & $\begin{array}{l}\text { Embung Kumpul } \\
\text { Rejo }\end{array}$ & 14 & 12.4 & 1.6 \\
\hline 12 & $\begin{array}{l}\text { Embung } \\
\text { Candirejo }\end{array}$ & 130.2 & 128.1 & 2.1 \\
\hline 13 & $\begin{array}{l}\text { Embung Kopeng } \\
2\end{array}$ & 6.8 & 6.5 & 0.3 \\
\hline 14 & $\begin{array}{l}\text { Embung Kopeng } \\
1\end{array}$ & 11.1 & 10.8 & 0.3 \\
\hline 15 & Embung Wates & 19.8 & 18.9 & 0.9 \\
\hline 16 & $\begin{array}{l}\text { Embung } \\
\text { Manggihan }\end{array}$ & 74.5 & 74.2 & 0.3 \\
\hline 17 & $\begin{array}{l}\text { Embung } \\
\text { Nogosaren }\end{array}$ & 5.4 & 5 & 0.4 \\
\hline 18 & Embung Kalibeji & 18.7 & 18.1 & 0.6 \\
\hline 19 & $\begin{array}{l}\text { Embung } \\
\text { Rowosari }\end{array}$ & 161 & 160.1 & 0.9 \\
\hline 20 & $\begin{array}{l}\text { Embung } \\
\text { Sepakung }\end{array}$ & 9.6 & 3.5 & 6.1 \\
\hline 21 & $\begin{array}{l}\text { Embung } \\
\text { Kebumen }\end{array}$ & 29.8 & 28.9 & 0.9 \\
\hline 22 & $\begin{array}{l}\text { Embung Tegaron } \\
1\end{array}$ & 2.4 & 2.2 & 0.2 \\
\hline 23 & $\begin{array}{l}\text { Embung Tegaron } \\
2\end{array}$ & 2.3 & 2.1 & 0.2 \\
\hline 24 & $\begin{array}{l}\text { Embung Tegaron } \\
3\end{array}$ & 3 & 2.9 & 0.1 \\
\hline 25 & $\begin{array}{l}\text { Embung } \\
\text { Kebundowo } 3\end{array}$ & 9.3 & 9.1 & 0.2 \\
\hline
\end{tabular}

\begin{tabular}{|c|c|c|c|c|}
\hline No & Embung & $\begin{array}{c}\text { Inflow } \\
\left(\mathbf{m}^{3} / \mathbf{s}\right)\end{array}$ & $\begin{array}{l}\text { Outflow } \\
\left(\mathrm{m}^{3} / \mathbf{s}\right)\end{array}$ & $\begin{array}{c}\text { Discharge } \\
\text { Reduction } \\
\left(\mathbf{m}^{3} / \mathbf{s}\right)\end{array}$ \\
\hline 26 & $\begin{array}{l}\text { Embung } \\
\text { Wirogomo 1 }\end{array}$ & 28.9 & 28.3 & 0.6 \\
\hline 27 & $\begin{array}{l}\text { Embung } \\
\text { Wirogomo } 2\end{array}$ & 27.7 & 26.2 & 1.5 \\
\hline 28 & $\begin{array}{l}\text { Embung } \\
\text { Banyubiru }\end{array}$ & 35.7 & 35.2 & 0.5 \\
\hline 29 & $\begin{array}{l}\text { Embung } \\
\text { Kebundowo 1 }\end{array}$ & 1.9 & 1.8 & 0.1 \\
\hline 30 & $\begin{array}{l}\text { Embung } \\
\text { Kebundowo } 2\end{array}$ & 2.3 & 1.9 & 0.4 \\
\hline 31 & Embung ngrapah & 2.8 & 2.1 & 0.7 \\
\hline 32 & $\begin{array}{l}\text { Embung } \\
\text { Kalimalang }\end{array}$ & 6.7 & 6.4 & 0.3 \\
\hline 33 & $\begin{array}{l}\text { Embung Ngrapah } \\
2\end{array}$ & 117.8 & 117.3 & 0.5 \\
\hline 34 & $\begin{array}{l}\text { Embung } \\
\text { Brongkol } 2\end{array}$ & 90 & 89 & 1 \\
\hline 35 & Embung Rejosari & 47 & 44.9 & 2.1 \\
\hline 36 & $\begin{array}{l}\text { Embung } \\
\text { Brongkol } 1\end{array}$ & 14.6 & 14.2 & 0.4 \\
\hline 37 & Embung Jambu & 27.4 & 25.3 & 2.1 \\
\hline 38 & $\begin{array}{l}\text { Embung } \\
\text { Pojoksari }\end{array}$ & 63.6 & 62.7 & 0.9 \\
\hline 39 & Embung Baran & 32.5 & 31.8 & 0.7 \\
\hline 40 & $\begin{array}{l}\text { Embung } \\
\text { Banyukuning }\end{array}$ & 63.6 & 62.7 & 0.9 \\
\hline
\end{tabular}

In addition to the known reduction in each sub-basin, it is known that the overall flood reduction that goes into Swamp Pening is from $975.80 \mathrm{~m}^{3} / \mathrm{s}$ to $560.30 \mathrm{~m}^{3} / \mathrm{s}$. The flood hydrograph before and after the construction of embungs in the Rawa Pening catchment area is shown on Figure 3 below.

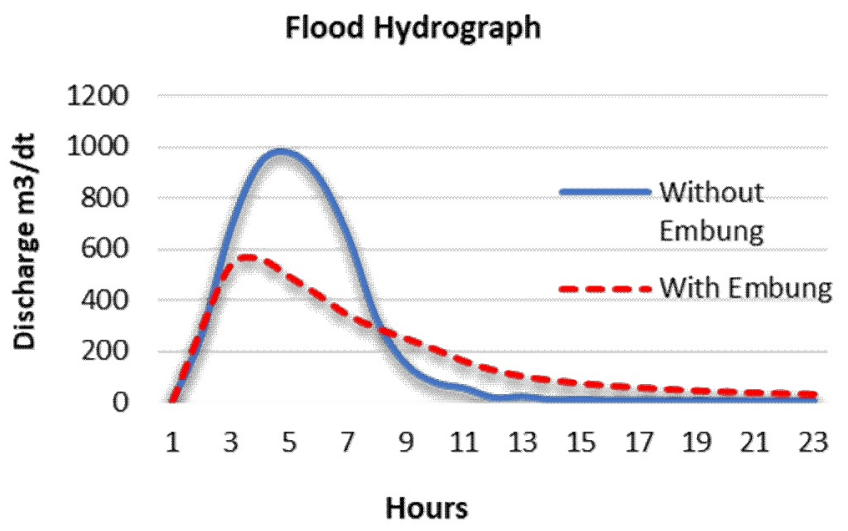

Figure 3. Flood Hydrograph Before and After Development of Potential Embung in Rawa Pening Catchment Area

The ranking review of the order of development of each alternative embung is done by means of multicriteria analysis. The criteria used in the ranking include several aspects related to the construction of embungs such as flood reduction, land use, embung volume, sedimentation and debit pledge. The criteria are then determined the value of the following interval with the 
value of each. The following are the criteria used in the analysis of alternative selection and value of each.

Tabel 2. Criteria Selection of Embung and The Value

\begin{tabular}{c|c|c|}
\hline \multicolumn{2}{c|}{ Flood Reduction } \\
\hline $\begin{array}{c}\text { Interval } \\
\left(\mathrm{m}^{3} / \mathrm{dt}\right)\end{array}$ & \multicolumn{2}{|c|}{ Value } \\
\hline $0,0-1,5$ & $\mathrm{E}$ & 1 \\
\hline $1,6-3,0$ & $\mathrm{D}$ & 2 \\
\hline $3,1-4,5$ & $\mathrm{C}$ & 3 \\
\hline $4,6-6,0$ & $\mathrm{~B}$ & 4 \\
\hline$>6,1$ & $\mathrm{~A}$ & 5 \\
\hline $\begin{array}{c}\text { Interval } \\
\text { (thousand } \\
\left.\mathrm{m}^{3}\right)\end{array}$ & \multicolumn{2}{c|}{ Value } \\
\hline $0,0-700$ & $\mathrm{E}$ & 1 \\
\hline $701-1400$ & $\mathrm{D}$ & 2 \\
\hline $1401-2100$ & $\mathrm{C}$ & 3 \\
\hline $2101-2800$ & $\mathrm{~B}$ & 4 \\
\hline$>2800$ & $\mathrm{~A}$ & 5 \\
\hline
\end{tabular}

\begin{tabular}{c|c|c|}
\hline \multicolumn{3}{|c|}{ Discharge } \\
\hline $\begin{array}{c}\text { Interval } \\
3 \\
\left(\mathrm{~m}^{/ \mathrm{dt}}\right)\end{array}$ & Value & \\
\hline $0,0-0,5$ & $\mathrm{E}$ & 1 \\
\hline $0,51-1,0$ & $\mathrm{D}$ & 2 \\
\hline $1,1-1,5$ & $\mathrm{C}$ & 3 \\
\hline $1,6-2,0$ & $\mathrm{~B}$ & 4 \\
\hline
\end{tabular} \mid \begin{tabular}{c|c|c|c|}
\hline $\begin{array}{c}\text { Interval } \\
\text { (thousand } \\
\text { ton })\end{array}$ & Value & \\
\hline $0,0-40,0$ & $\mathrm{~A}$ & 5 \\
\hline $40,1-80,0$ & $\mathrm{~B}$ & 4 \\
\hline $80,1-120,0$ & $\mathrm{C}$ & 3 \\
\hline $120,1-160,0$ & $\mathrm{D}$ & 2 \\
\hline$>160,1$ & $\mathrm{E}$ & 1 \\
\hline
\end{tabular}

\begin{tabular}{c|c|}
\hline Type & Value \\
\hline Settlement & 5 \\
\hline Rice Field & 10 \\
\hline Moor & 15 \\
\hline bush & 30 \\
\hline forest & 40 \\
\hline
\end{tabular}

In addition to the assessment of each criterion, analyzed also the weight of each of these criteria. It is necessary to determine which criteria are more important

Tabel 3. Weight of Each Criteria

\begin{tabular}{|c|c|c|}
\hline Criteria & \multicolumn{2}{|c|}{ Weight } \\
\hline Flood Reduction & A & 5 \\
\hline Land Use & B & 4 \\
\hline Embung Volume & C & 3 \\
\hline Sedimentation & D & 2 \\
\hline Mainstay Debit & E & 1 \\
\hline
\end{tabular}

The score of each embung is the sum of the values multiplied by the weights for all of the above criteria. The results of matrix analysis of the selection of the top 5 (five) rating spots are shown on Table 4.

Tabel 4. Matrix of Election Analysis of Embung

\begin{tabular}{|c|c|c|c|c|c|c|c|}
\hline $\begin{array}{c}\text { Em } \\
\text { bung }\end{array}$ & Value & $\begin{array}{c}\text { Flood } \\
\text { Reduc- } \\
\text { tion }\end{array}$ & $\begin{array}{l}\text { Land } \\
\text { Use }\end{array}$ & $\begin{array}{c}\text { Volume } \\
\text { Embung }\end{array}$ & $\begin{array}{l}\text { Sedimen- } \\
\text { tation }\end{array}$ & $\begin{array}{r}\text { Dis- } \\
\text { charge }\end{array}$ & $\begin{array}{l}\text { Total } \\
\text { Value }\end{array}$ \\
\hline \multirow{3}{*}{$\begin{array}{l}\text { Sepa- } \\
\text { kung }\end{array}$} & Value & 5 & 5 & 2 & 5 & 1 & \multirow{3}{*}{62} \\
\hline & Weight & 5 & 4 & 3 & 2 & 1 & \\
\hline & Result & 25 & 20 & 6 & 10 & 1 & \\
\hline \multirow{3}{*}{$\begin{array}{c}\text { Rejo- } \\
\text { sari }\end{array}$} & Value & 2 & 3 & 5 & 5 & 2 & \multirow{3}{*}{49} \\
\hline & Weight & 5 & 4 & 3 & 2 & 1 & \\
\hline & Result & 10 & 12 & 15 & 10 & 2 & \\
\hline \multirow{3}{*}{ Batur } & Value & 1 & 5 & 2 & 5 & 1 & \multirow{3}{*}{42} \\
\hline & Weight & 5 & 4 & 3 & 2 & 1 & \\
\hline & Result & 5 & 20 & 6 & 10 & 1 & \\
\hline \multirow{3}{*}{ Taju } & Value & 3 & 2 & 2 & 5 & 1 & \multirow{3}{*}{40} \\
\hline & Weight & 5 & 4 & 3 & 2 & 1 & \\
\hline & Result & 15 & 8 & 6 & 10 & 1 & \\
\hline \multirow{3}{*}{$\begin{array}{l}\text { Wiro- } \\
\text { gomo } 1\end{array}$} & Value & 1 & 5 & 1 & 5 & 1 & \multirow{3}{*}{39} \\
\hline & Weight & 5 & 4 & 3 & 2 & 1 & \\
\hline & Result & 5 & 20 & 3 & 10 & 1 & \\
\hline \multirow{3}{*}{$\begin{array}{c}\text { Kopeng } \\
2\end{array}$} & Value & 1 & 5 & 1 & 5 & 1 & \multirow{3}{*}{39} \\
\hline & Weight & 5 & 4 & 3 & 2 & 1 & \\
\hline & Result & 5 & 20 & 3 & 10 & 1 & \\
\hline
\end{tabular}

\section{CONCLUSION}

From this research, there are 40 potential locations of embungs in 16 tributaries entering Rawa Pening. This study proves that the embungs in the Rawa Pening Watershed can reduce the magnitude of the massive flood hydrograph. Flood mitigation capability of each embung is the main criterion in fracturing of embung with "Weighted Average" method.

The main conclusion that can be taken as an innovation from the results of this research is the construction of embungs in the Rawa Pening Watershed is an effort to maintain the function and its natural containment. So that the flood outflow will be reduced due to the container, so the risk of flooding along the Tuntang River can be reduced. Further research in accordance with the "Road Map" can be expected of the upstream embungs can be used as a place to hold sediment in the upstream that want to enter, so that the quality of Rawa Pening inflow water will be improved. Similarly, the growth rate of Eceng Gondok can be suppressed.

Fishery cultivation with floating nets in the Rawa Pening water body can be removed and moved to the embungs in the upstream. Meanwhile, the cultivation of catch fish in Rawa Pening can keep growing. 


\section{ACKNOWLEDGMENTS}

Thank you so much for the Mayor of Pemal River Juana Directorate General of Water Resources Ministry of PUPR for the help and data used to carry out this research.

\section{REFERENCES}

1. Konecny, F., \& Strauss, P. Hyetograph Simulation of High-Intense Rainfall Events 2. Summary of the Scaling Model of Storm Hydrograph. In hydrologic days. (2008).

2. Prasasti, I., Sofan, P., Febrianti, N., \& Suprapto, T. Pemanfaatan Data Penginderaan Jauh Untuk Analisis. Seminar Nasional Penginderaan Jauh, (Gambar 1), 577-587.(2014).

3. Natakusumah, Dantje K., Dhemi Harlan, Harlan, D. Prosedur Umum Perhitungan Hidrograf Satuan Sintetis dengan Cara ITB dan Beberapa Contoh Penerapannya. Jurnal Teknik Sipil, 18(3), 251-291. (2011a).

4. D. Roy, S. Begam, S. G. and S. J. Calibration and Validation of Hec-Hms Model for a River Basin in Eastern India. Journal of AEngineering and Applied Sciences, 8(1), 40-56. (2013).

5. Valdes, J. B., \& Marco, J. B. Managing reservoirs for flood control. In US-Italy research workshop on the hydrometeorology, impacts, and management of extreme floods (pp. 1-13). Tucson: U.S.- Italy Research Workshop on the Hydrometeorology, Impacts, and Management of Extreme Floods. (1995).

6. Fasahat, V., Honarbakhsh, A., Samadi, H., \& Sadatinejad, S. J. Hydrological Flood Routing in Rivers. International Research Journal of Applied and Basic Sciences, 4(10), 3301-3305. (2013).
7. Scharffenberg, M. F. Hydrologic Modeling System (Hec-Hms):New Features For Urban Hydrology. (2006).

8. Emiroglu, M. E. Influences on Selection of the Type of Dam. International Journal of Science \& Technology, 3(2), 173-189. (2008).

9. Lian, J., Yao, Y., Ma, C., \& Guo, Q. Reservoir Operation Rules for Controlling Algal Blooms in a Tributary to the Impoundment of Three Gorges Dam, (2014).

10. Natakusumah, Dantje K. , Dhemi Harlan, Harlan, D. Prosedure Umum Perhitungan Hidrograph Satuan Sintetis (Hss) Untuk Perhitungan Hidrograph Banjir Rencana. Studi Kasus Penerapan Hss Itb-1 Dan Hss Itb-2 Dalam Penentuan Debit Banjir Untuk Perencanaan Pelimpah Bendungan Besar. In Prosedure Umum Perhitungan Hidrograph Satuan Sintetis (Hss) Untuk Perhitungan Hidrograph Banjir Rencana. Studi Kasus Penerapan Hss Itb-1 Dan Hss Itb-2 Dalam Penentuan Debit Banjir Untuk Perencanaan Pelimpah Bendungan Besar (pp. 123). (2011b). Bandung. Retrieved from https://docs.google.com/viewer?url=https $\% 3 \mathrm{~A} \% 2 \mathrm{~F}$ $\% 2 \mathrm{Fwww}$. researchgate.net\%2Fprofile\%2FDhemi_ Harlan\%2Fpublication\%2F282779944_Prosedur_U mum_Perhitungan_Hidrograph_Satuan_Sintetis_(H SS)_untuk_Perhitungan_Hidrograph_Banjir_Renca na._Studi_Kasus_Penerapan_HSS_ITB-

11. Reza, M., \& Ready, A. Evaluasi Perhitungan Debit Banjir Rencana Dengan Hidrograf Metode Itb , Nakayasu, Snyder Pada Sub. Jakarta. (2012).

12. U.S. Army Corps of Engineers. Hydrologic Modeling System User 's Manual. (2016). 